\title{
Management of ophthalmic surgical instruments and processes optimization: mixed method study
}

\author{
Gerenciamento de instrumentais oftalmológicos e otimização \\ de processos: estudo de método misto \\ Gestión de instrumentales quirúrgicos oftalmológicos y \\ optimización de procesos: estudio de método misto \\ Daniela Silva dos Santos Schneider ${ }^{a, b}$ \\ Ana Maria Müller de Magalhães ${ }^{a, b}$ \\ Cecília Helena Glanznerc \\ Elisabeth Gomes da Rocha Thoméc \\ João Lucas Campos de Oliveira ${ }^{\mathrm{d}}$ \\ Michel José Anzanello
}

How to cite this article:

Schneider DSS, Magalhães AMM,

Glanzner CH, Thomé EGR, Oliveira

$J L C$, Anzanello MJ. Management of ophthalmic instruments and optimization of processes: mixed method study. Rev Gaúcha Enferm. 2020;41:e20190111. doi: https://doi.org/10.1590/19831447.2020.20190111 a Hospital de Clínicas de Porto Alegre (HCPA). Porto Alegre, Rio Grande do Sul, Brasil.

' Universidade Federal do Rio Grande do Sul (UFRGS), Escola de Enfermagem, Programa de Pós-Graduação em Enfermagem. Porto Alegre, Rio Grande do Sul, Brasil.

Universidade Federal do Rio Grande do Sul (UFRGS), Escola de Enfermagem, Departamento Enfermagem Médico-Cirúrgica. Porto Alegre, Rio Grande do Sul, Brasil.

d Universidade Federal do Rio Grande do Sul (UFRGS), Escola de Enfermagem, Departamento de Assistência e Orientação Profissional. Porto Alegre, Rio Grande do Sul, Brasil.

Universidade Federal do Rio Grande do Sul (UFRGS), Escola de Engenharia, Departamento de Engenharia de Produção e Transportes. Porto Alegre, Rio Grande do Sul, Brasil.

\section{ABSTRACT}

Aim: Analysis of the use of ophthalmic instruments during surgical procedures in order to propose a material management method. Method: Mixed method study, sequential exploratory design, performed from January to June 2015, at a university hospital in southern Brazil. First, a qualitative approach was held from brainstorming and field observation. Themes were grouped into thematic categories. By connection, the quantitative stage happened through matrix arrangement and linear programming, culminating in the instrument management proposal.

Results: Given categories - instruments reorganization according to the time of the surgical procedure and the need surgical instruments for in each procedure - guided the definition of existing restrictions and application of mathematical models. There was an average reduction of $13.10 \%$ in the number of surgical instruments per tray and an increase of $17.88 \%$ in surgical production.

Final considerations: This proposal allowed the rationalization and optimization of ophthalmic instruments, favoring sustainability of the organization.

Keywords: Sterilization. Quality management. Materials management, hospital.

RESUMO

Objetivo: Analisar o uso de instrumentais oftalmológicos durante os procedimentos cirúrgicos e propor um método de gerenciamento de materiais.

Método: Estudo de método misto, exploratório sequencial, realizado entre janeiro e junho de 2015, em hospital universitário no sul do Brasil. Primeiramente, fez-se uma abordagem qualitativa a partir de brainstorming e observação de campo. Os temas foram agrupados em categorias temáticas. Por conexão, a etapa quantitativa aconteceu por arranjos de matrizes e programação linear, culminando à proposta de gerenciamento de instrumentais.

Resultados: As categorias - reorganização do instrumental conforme tempo do procedimento cirúrgico e necessidade de peças para cada procedimento - orientaram a definição das restrições existentes e aplicação dos modelos matemáticos. Verificou-se uma redução média de 13,10\% no número de peças por bandejas e aumento de 17,88\% da produção cirúrgica.

Considerações finais: Esta proposta permitiu a racionalização e otimização de instrumentais oftalmológicos, favorecendo a sustentabilidade da organização.

Palavras-chave: Esterilização. Gestão da qualidade. Administração de materiais no hospital.

\section{RESUMEN}

Objetivo: Analizar el uso de instrumentos oftalmológicos durante los procedimientos quirúrgicos y proponer un método de gestión de materiales.

Método: Estudio de método mixto, exploratorio secuencial, realizado entre enero y junio de 2015, en un hospital universitario en el sur de Brasil. Primero, se realizó un enfoque cualitativo a partir de la reflexión y la observación de campo. Los temas se agruparon en categorías temáticas. Por conexión, la etapa cuantitativa ocurrió por arreglos de matrices y programación linear, culminando con la propuesta de gestión de instrumentales.

Resultados: Las categorías - reorganización del instrumental conforme tiempo del procedimiento quirúrgico y necesidad de piezas para cada procedimiento - orientaron la definición de las restricciones existentes y aplicación de los modelos matemáticos. Verificó una reducción media del 13,10\% en el número de piezas por bandejas y aumento del 17,88\% de la producción quirúrgica.

Consideraciones finales: Esta propuesta permitió la racionalización y optimización de instrumentos oftalmológicos, favoreciendo la sostenibilidad de la organización.

Palabras clave: Esterilización. Gestión de la calidad. Administración de materiales de hospital. 


\section{口INTRODUCTION}

The challenges of hospital institutions increase continuously to improve the quality of services offered to society ${ }^{(1-2)}$. In this context, the Central Sterile Services Department (CSSD) is responsible for processing health materials and products, contemplating actions that start immediately before and after the direct assistance, which directly affects the safe or unsafe care to the patient, an elementary dimension in health quality ${ }^{(3)}$.

The management of institutional material and financial resources is reason for studies and is a concern in institutions that operate with the Single Health System (SHS) and have also gained emphasis in the scientific literature ${ }^{(2)}$. Limited budgets combined to the needs for assisting a population with increasingly higher lifespan and the use of new technologies, in addition to the lack and/or deficiency of number of beds and institutional structures drive the development of strategies aiming at more efficient systems that will favor care quality and safety ${ }^{(4)}$.

The search for practices that will assure the patient's safety has been increasingly discussed in national and international debates in the different health areas. In Brazil, inefficient health planning is one of the problems that compromise quality and causes insecurity in care ${ }^{(4)}$. The lack and/or deficiency of planning in health institutions tend to cause failures in care quality and cause unnecessary and avoidable suffering to patients, such as temporary or permanent limitations ${ }^{(5)}$.

One of the most complex cares in health institutions concerns surgical procedures, and it is known that in this care scope there are frequent adverse events that could be avoided ${ }^{(6)}$. There are underreporting in most countries, however, perioperative death rate ranges from $0.4 \%$ to $0.8 \%$ and the rate of severe surgical complications reaches $17 \%$ in developed countries ${ }^{(4)}$. It is also estimated that these rates are even higher in developing countries, because there are few studies evidencing such occurrences in these contexts ${ }^{(4)}$.

In a literature review by researchers from England it is demonstrated that 1 out of each 20 surgical patients experienced an undesirable and avoidable event during care, a fact that reinforces the need to improve all processes involving surgical care ${ }^{(7)}$. With regard to ophthalmic surgeries, among the possible adverse events are visual deficiencies and loss of vision, to, making feasibal an environment with effective and stable communication is a way to minimize occurrences of errors, making surgical processes safer ${ }^{(8)}$. Thus, the importance of investing in planning and appropriate management of materials used in ophthalmic surgeries is considered. Taking into consideration the specificity, sensitivity and high cost of instruments required, factors that can directly impact not just on the quality of care but on reduction of costs for institutions, as well.

In face of the complexity of the surgical work, as well as inputs involving it, it is known that the nurse, in this context, plays essential role in the management, both of human resources and physical and environment resources ${ }^{(1)}$. This complex task contemplates construction, organization, planning and systematization of processes that not only involve the nursing work, but also interferes with surgical care ${ }^{(9)}$.

CSSD nurses, in their daily process management activities, in order to ensure safety in sterilization of materials used in surgeries - including ophthalmic ones - identified the existence of room to improve and optimize the activities, thus bringing better results to patients and to the institution. With regard to this optimization, previous study demonstrates that, on average, only 13 to $25 \%$ on trays' instruments are actually used during surgical procedures ${ }^{(10)}$.

The adoption of systems for control, prediction and provision of efficient materials is essential to avoid failures in the process that can pose risks to patients. In this context, the nurse assumes essential role in the management of these processes, fomenting the use of methodologies and tools to diagnose, evaluate and solve difficulties in real time, minimizing institutional costs and ensuring continuation of the work with more safety, efficiency and efficacy in surgical rooms $s^{(9)}$.

In face of the considerations presented that result in the justification to perform studies that in fact present feasible strategies for optimization of materials' management processes, this work is intended to answer the following research question: How to manage and optimize the use of ophthalmic surgical instruments? Seeking answers to this question, the present study aims at analyzing the use of ophthalmic instruments during surgical procedures and proposing a method for management of materials. -

\section{—METHOD}

Study designed by mixed method, with sequential exploratory design ${ }^{(11)}$. For such, a first stage of qualitative approach was organized based on brainstorming and field observation ${ }^{(11-12)}$ followed by quantitative stage, using matrix arrangement methodology and linear programming ${ }^{(13-14)}$.

In this research, data were equally treated, that is, weight was not assigned to qualitative or quantitative data. However, the procedure of connection of first stage data analysis and second stage collection was respected to characterize the research as mixed in sequential performance ${ }^{(15)}$. 
The study was conducted in the CSSD of a Federal University Hospital in Rio Grande do Sul, Brazil. Ophthalmic surgery specialty was defined as the object of the study due to the high volume of procedures (3,248 procedures in 2015 and 3,424 in 2016), the high amount of instruments in trays and frequent occurrence of emergency requests for processing these materials.

The team responsible for processing materials in CSSD comprises 72 professionals, including nursing assistants (LPN), nine registered nurses - RN (eight of them assistant and one coordinator of the unit), in addition to one administrative assistant. The sector provides 24/7 care.

All professionals working on a daily basis with ophthalmic procedures were invited to participate, and were informed of the study's purposes, form of participation, risks and benefits. The right to leave the study at any moment was guaranteed to all, without any professional harm. It was made clear that voluntary participation would not represent any financial advantage, and that all activities involved would be performed during their shifts and adapted to the processes that they usually executed.

With regard to possible benefits, they were instructed on the possibilities of rationalization and optimization of resources, as well as improvement of processes, with reflex on the quality and safety of ophthalmic surgical procedures. It was also explained that the results from the study, which could be incorporated in their daily practice would be shared with participants.

In the qualitative stage, the study's first stage, brainstorming was used focused on the group creativity and capacity, in the shortest possible time. In this technique all ideas are seen by all and none of them can be criticized or rejected ${ }^{(11)}$. The research coordinator act as moderator of the groups, conducting the discussions and seeking consensus to organize the proposals, as recommends the brainstorming technique ${ }^{(11)}$. In addition to the ideas stimulation technique, field observation was later performed.

The group discussions guided by brainstorming occurred during January to April 2015. In this stage, 10 pre-scheduled meetings were held in CSSD, with the sector's specialists (surgeons and nursing surgical assistant), one registered nurse and one licensed practical nurse (LPN) com, comprising an average of 4-5 participants in each group. In this stage eight surgeons, five nursing surgical assistant, three licensed practical nurses and one registered nurse. Each meeting lasted one hour on average, annotations were recorded and later transcribed.
The researcher defined and organized the meetings in an environment that would ensure privacy of participants. Discussions were focused on the use of instruments grouped according to their use in the surgical time, simulating the sequence of use during the procedure. In group discussion questioning and reflections on the use of each instrument in the surgical trays occurred. These stages were intended to identify the actual use of instruments and allocate them rationally in different trays according to the surgical procedure.

In the shift or day immediately after the group meeting, review of instruments was made, organizing the new trays and forwarding them for test in the procedure in the surgical ward. At the surgery moment, field observation techniques were used and immediately after the conclusion of each procedure, a new meeting of the group was held for discussion and adaptation of the new trays' proposals. The changes made were validated in this meeting of nursing surgical assistant, surgeons and research team, and counted on the participation of the surgical ward leaders. Based on the feedbacks provided by these professionals, eventual corrections and/ or reviews were made, generating new descriptions of the process and guidance to CSSD and Surgical Ward work teams.

In this study, it was considered that the procedure involving meeting/observation - discussion - adjustments - new meeting - new adjustments, determined the stage of data analysis itself of the study qualitative phase. That because, at each meeting pre-analysis was performed (survey of central ideas from brainstorming and field observation); exploration of material, treatment of results obtained and interpretation (systematization in thematic categorization of the meetings content), according to reference of thematic content analysis technique ${ }^{(16)}$.

Such information subsidized - by connection - the collection and organization of the quantitative stage data, which were summarized in electronic spreadsheet describing the type of procedure, type and number of each instrument used, obeying to matrix array. This whole stage was developed with Production Engineering advice.

From that, the quantitative stage was started, developed from May to June 2015. All procedures made in the period were included in the sample. In this matrix, based on categorization of the study qualitative stage data, procedures were placed in lines and the indication of the need of instruments were place in columns (for example, all instruments required for a given procedure is shown with number "1" in line-column crossing). Then, Close Neighbor Algorithm (CNA) ${ }^{(13)}$ was applied to form groups to the mentioned matrix. 
In the initial matrix, CNA performed a first stage, which is reordering of lines. In this new design of the matrix stage two was performed, with reorganization of columns. Upon conclusion of these two phases, agglomerations of incidences in the main diagonal of the new matrix could be identified ${ }^{(13)}$, suggesting formation of trays, among other conclusions.

This matrix array made possible the grouping of instruments according to their demand by a given group of surgeries, with easy visualization of procedures that demanded the same inputs, and therefore, culminating in the optimization of management processes. Therefore, grouping of materials (which may suggest composition of new trays) destined to the execution of a given group of surgical procedures were generated.

To complement information generated by CNA application, linear programming was used for optimization of the amount of trays against factors like demand for surgical procedures and other practical restrictions (like cost for composition of a new tray, for example).

For linear programming restrictions to the system were considered as follows: (i) need to use one same tray for different procedures (availability of trays); (ii) time of processing by CSSD; (iii) availability of professionals per week day and shift, (iv) surgery time. As result, it was observed the need of reorganization of the surgical scale used until then.

The study observed National Health Council Resolution no 466/12 and was registered in the institution's Ethic and Research Committee obtaining approval under opinion number 2.183.123/2015.

\section{口 RESULTS}

Qualitative information was grouped and emerged two categories: instruments reorganization according to surgical procedure time and need of pieces for each procedure. The discussion in groups made possible the visualization of the theme studied, questionings, reflection on the processes developed in processing and use of ophthalmic surgical materials, experiences in face of the researcher proposals and those generated by the group, and the aspects involved in the work organization.

From the information provided by the specialists, rationalization* and reallocation of instruments in different trays occurred. With the new arrangement, average reduction of $13.10 \%$ in the number of pieces per tray was verified. In four trays there was no reduction of instruments; in the others, reduction percent ranged from $5.56 \%$ to $59.26 \%$, which showed clear possibility of rearrangement of materials in other trays (Table 1).
The application of matrix array method and linear programming was made in 20 ophthalmic procedures in order to assess surgeries' demands, materials required for each procedure and their scheduling in the surgery work schedule.

The review of the whole process of application of this methodology made possible the adaptation of purchase planning and investment in instruments to meet surgical demand with safety. The reorganization of trays resulted in reduction in institutional costs due to the reduction in the number of instruments to be acquired. Such economy was estimated in R\$ 420,000 (approximately U\$ 133,000 according to quotation of the period when the study was performed).

With the use of CNA, the interaction of trays and procedures could be verified, through sequential ordering of lines and columns. The array drawing (marked areas) identified the need of one same tray for different procedures (Figure 1).

The ophthalmic surgical schedule, characterized by reduced times for procedures execution and high number of procedures, used to cause inconveniences involving delays due to lack of material, cancellations and risks of surgeries. With the identification of opportunities to improve, the maximum number of possible surgeries was calculated considering four restrictions (R): availability of trays, processing time, availability of professionals, and surgery time. Chart 1 shows the example of this calculation using linear programming. In this case, Monday was selected as the day of the week, morning shift, and the four restrictions previously described. Based on the result of the number of procedures that could be performed, the surgical schedule was reorganized.

In addition to benefits resulting from indicators of reduction in the amount of instruments belonging to ophthalmic surgery trays and restrictions, it was also observed increase in surgical production. This increase was possible through the removal of extra instruments from the trays and later creation of new sets. The availability of identical trays, without new investments, made possible immediate scheduling of higher number of surgeries. According to institutional data on surgical production referring to the amount of ophthalmic procedures performed annually, $17.88 \%$ increase was observed against production before rationalization. This analysis was generated from the use of information associated to the types of surgical procedures, used in the study's qualitative stage.

\footnotetext{
* Rationalization is understood as a rational way of organizing materials aiming at productivity, efficiency and
} efficacy to achieve the desired results. 


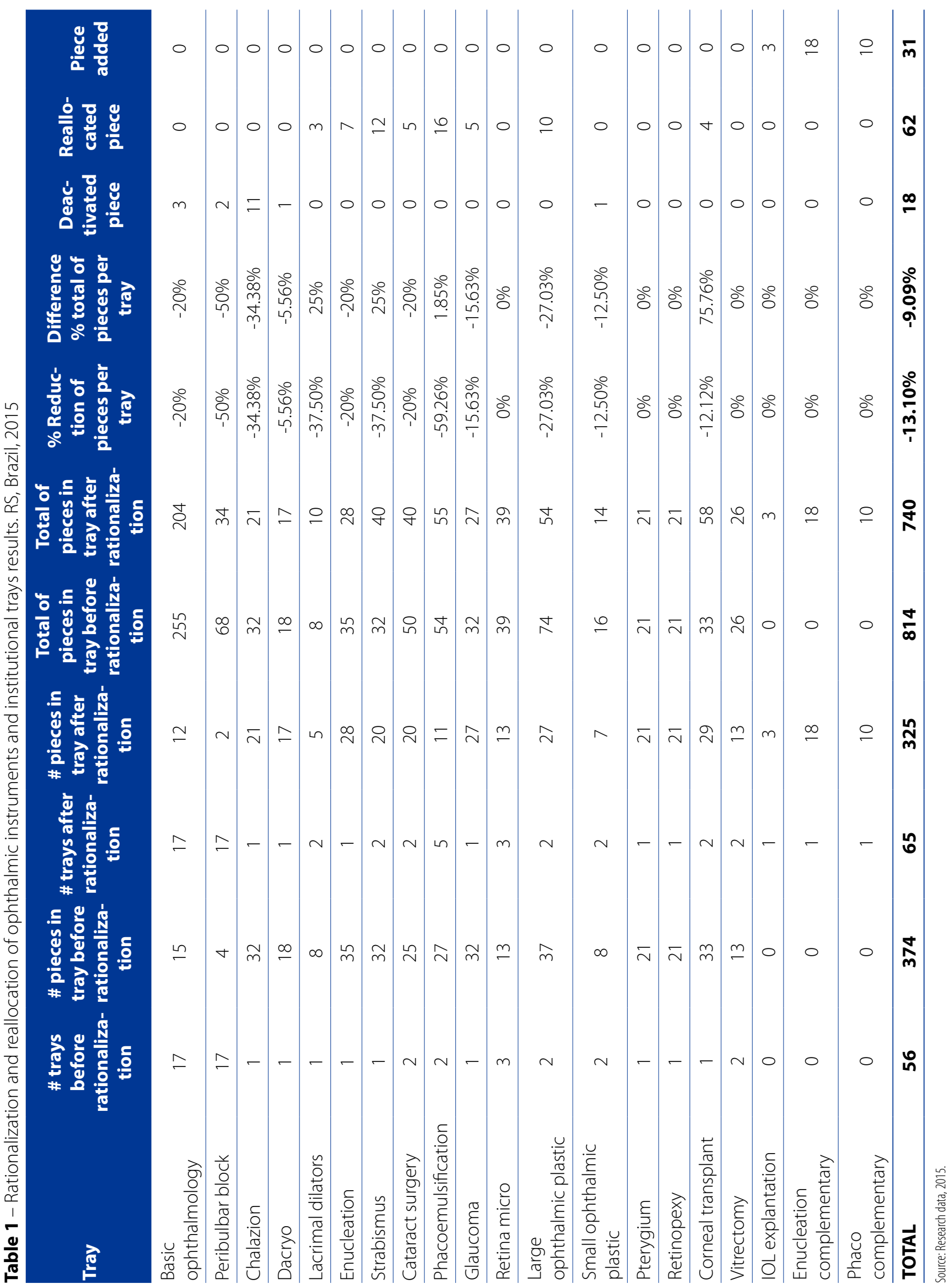




\begin{tabular}{|c|c|c|c|c|c|c|c|c|c|c|c|c|c|c|c|c|c|c|c|c|c|c|c|c|c|c|}
\hline Tray & 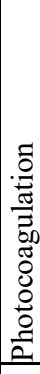 & 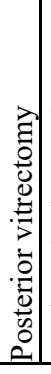 & 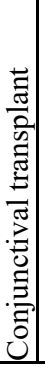 & 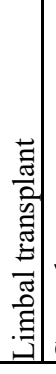 & 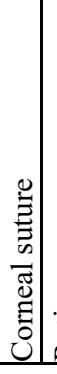 & 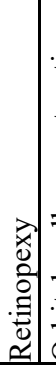 & 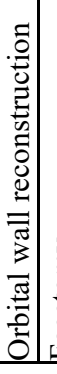 & 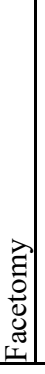 & 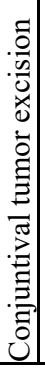 & 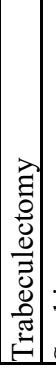 & 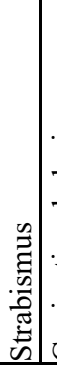 & 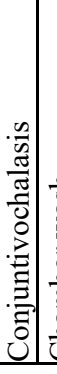 & 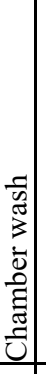 & 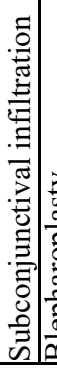 & 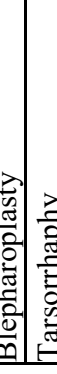 & & 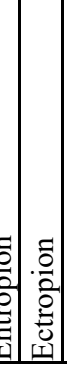 & 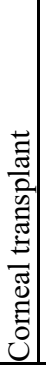 & 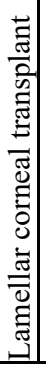 & 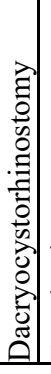 & 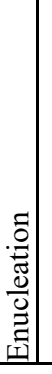 & 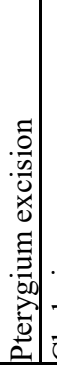 & 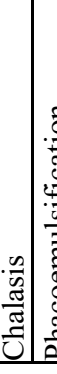 & 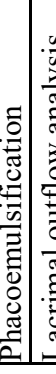 & 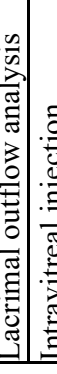 & 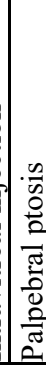 \\
\hline Basic ophmalogic tray & 1 & 1 & 1 & 1 & 1 & 1 & 1 & 1 & 1 & 1 & 1 & 1 & 1 & 11 & 11 & 11 & 1 & 1 & 1 & 1 & 1 & 1 & 11 & 11 & 11 & 1 \\
\hline Peribulbar block tray & 1 & 1 & 1 & 1 & 1 & 1 & 1 & 1 & 1 & 1 & & 1 & 1 & & & & & 1 & 1 & & & & & 1 & & \\
\hline Cannula box & & 1 & 1 & 1 & & 1 & 1 & 1 & 1 & 1 & 1 & 1 & 1 & & & & & 1 & 1 & & & & & 1 & & \\
\hline Bipolar cutery pencil & & 1 & 1 & 1 & & 1 & 1 & 1 & 1 & 1 & 1 & & & & & & & 1 & 1 & & 1 & 1 & & & & \\
\hline Facectomy tray & & 1 & 1 & 1 & 1 & 1 & & 1 & 1 & & & 1 & 1 & & & & & & & & & & & & & \\
\hline Barraquer blepharostat & & 1 & & & & & & 1 & & 1 & & & 1 & 1 & & & & & & & & & & & 1 & \\
\hline Pterygium tray & 1 & & & & & & & & & & & & 1 & 1 & & & & & & & & & & & & \\
\hline Cotton tabs & & & & & 1 & & & & 1 & & 1 & & 1 & & 11 & & & & & & 1 & & & & 1 & \\
\hline Ophtalmo plastic tray & & & & & & & 1 & & & & & & & & 11 & $1 \mid 1$ & 1 & & & & & & & & & 1 \\
\hline Bipolar cautery pencil thick tip & & & & & & & & & & & & & & & 11 & & & & & & & & & & & \\
\hline Palpebral ptosis needle tray & & & & & & & & & & & & & & & 11 & & & & & & & & & & & \\
\hline Sleeve pneumatic & 1 & & & & & & & & & & & & & & & & & & & & & & & & & \\
\hline Retinopexy tray & 1 & & & & & 1 & & & & & & & & & & & & & & & & & & & & \\
\hline Battery cautery pen & & & & & & 1 & & & & & & & & & & & & 1 & 1 & & & 1 & & & & \\
\hline Trepan box & & & 1 & 1 & & & & & & & & & & & & & & 1 & 1 & & & & & & & \\
\hline Corneal transplant recipiente tray & & & & 1 & & & & & & & & & & & & & & 1 & 1 & & & & & & & \\
\hline Acess transplant box & & & & & & & & & & & & & & & & & & 1 & 1 & & & & & & & \\
\hline Corneal transplant donor tray & & & & & & & & & & & & & & & & & & & 1 & & & & & & & \\
\hline
\end{tabular}

Figure 1 - Application of matrix arrays method in ophthalmic instrument trays per surgical procedure. RS, Brazil, 2015

Source: Research data, 2015.

Captions: bdj.: tray; tx.: transplant; cx.: box.

\section{DISCUSSION}

Brainstorming-guided groups as participative research strategy made possible sharing of responsibilities with regard to the choice of instruments and optimization of their use in the listed procedures, and led to review and redistribution of trays. During the study, by implementing the agreed upon interventions with all those involved, it was possible to observe shared discussions and approximation of ophthalmology and CSSD teams. As a result, the acknowledgement and commitment with the best organization of instruments in trays were confirmed, which reduced the stock of instruments not used in trays during a procedure.

Most studies found make instrument analysis considering the need of one single type of procedure, which favors reduction in the number of pieces in trays, particularly when they are shared across procedures, which justifies the high numbers of reductions reported by these authors (10,17-18) $^{\text {. }}$

The literature on re-assessment of instruments in trays is mostly exclusively based on the observation of their use in a surgery sample and field observation ${ }^{(10,18-20)}$, however, in one study ${ }^{(18)}$ more similar to the present one, where a multidisciplinary group of specialists was formed to analyze pediatric surgery trays, average reduction of $27.8 \%$ was reported. This study corroborates our findins and the relevance of this multiprofessional discussion.

Reduction in the amount of instruments in ophthalmic surgery trays led to re-assessment of investments and improvement in safety to the surgical patient, ensuring availability of instruments at the right time for each procedure. Moreover, rationalization of the number of instruments per tray can have substantial impact on their processing costs with reduction in the stock of materials not used and those that need continuous processing ${ }^{(10,17,20)}$. Assessment of processes is an important tool to reduce costs in health services, where inefficient surgical routine can compromise safety of care and generate waste ${ }^{(19-20)}$.

In financial terms, it can be noticed that the re-assessment of the amount of pieces belonging to trays and surgical feasibility with application of linear programming made 


\begin{tabular}{|c|c|c|c|}
\hline Restriction & Trays & Amount available (units) & Amount used (units) \\
\hline \multirow{6}{*}{$\begin{array}{l}\text { RESTRICTION 1: } \\
\text { AVAILABILITY OF } \\
\text { TRAYS }\end{array}$} & a. Cannula box & 3 & 3 \\
\hline & b. Strabismus tray & 1 & 1 \\
\hline & c. Ophthalmic/Block Basic & 17 & 6 \\
\hline & d. Vitrectomy tray & 2 & 2 \\
\hline & e. Small plastic tray & 2 & 2 \\
\hline & f. Large plastic tray & 2 & 1 \\
\hline Restriction & Time to process ( $\mathrm{min}$ ) & Time available (min) & Time used (min) \\
\hline $\begin{array}{l}\text { RESTRICTION 2: } \\
\text { PROCESSING TIME }\end{array}$ & 180 & 720 & 600 \\
\hline Restriction & Physicians & Time available ( $\mathrm{min})$ & Time used (min) \\
\hline \multirow{2}{*}{$\begin{array}{l}\text { RESTRICTION 3: } \\
\text { AVAILABILITY OF } \\
\text { PROFESSIONALS }\end{array}$} & A & 360 & 240 \\
\hline & B & 180 & 180 \\
\hline Restriction & Procedure & Time (min) & Amount of procedures \\
\hline \multirow{5}{*}{$\begin{array}{l}\text { RESTRICTION 4: } \\
\text { SURGERY TIME }\end{array}$} & a. Strabismus & 60 & 1 \\
\hline & b. Posterior vitrectomy & 90 & 2 \\
\hline & c. Palpebral ptosis & 60 & 2 \\
\hline & d. Blepharoplasty & 60 & 1 \\
\hline & e. Suture & 60 & 0 \\
\hline \multicolumn{3}{|c|}{ Total of procedures that can be performed considering restrictions } & 6 \\
\hline
\end{tabular}

Chart 1 - Example of calculation using linear programming for scheduling of ophthalmic surgeries on Monday morning - RS, Brazil, May/June 2015.

Source: Research data, 2015.

possible to review orders of purchase for new trays. Such action responded for an expressive economy in the purchase of instrument when compared to the list prepared before this management. This result, replicating in large scale for other specialties and procedures, can represent an important economy in planning of hospital materials' replacement.

The findings involving rationalization in the use of materials, cost reduction and increase of surgical procedures converge with the results of other study that assessed the efficiency in the use of the surgery room to reduce costs ${ }^{(20)}$.

\section{FINAL CONSIDERATIONS}

With this study, a model for management of instruments could be developed that assesses existing restrictions, performs required adaptations and optimization of the use of instruments. It is understood that such changes can contribute to reduce risks, minimizing the insecurity inherent in a surgical procedure, in addition to contributing to organizational sustainability by means of rationalization of resources.

In addition to these benefits, the use of this proposal, adopting mixed methods approach where in the qualitative stage promoted a multi-professional and inter-sector discussion, drove the engagement of all in the creation of changes and improvement of work processes. Qualitative information guided the definition of existing restrictions and application of mathematic models that resulted in reduction of the number of instruments in trays. The model proposed should be assessed as to its relevance in other locations and surgical specialties.

The exclusive use for ophthalmology and the fact that it was performed in one single institution, a teaching institution, 
can be understood as limitations to this study. Despite these limitations, which don't allow generalization of its results, we understand that the study is innovative and relevant in the current scenario of health systems, bringing important contribution to the review of processes, impacting on institutions'sustainability. It is also understood that, based on the proposed management, improvements can be identified in the process of planning surgery schedule.

\section{$\square$ REFERENCES}

1. Bogo PC, Bernardino E, Castilho V, Cruz EDA. The nurse in the management of materials in teaching hospitals. Rev Esc Enferm USP. 2015 Aug;49(4):632-9. doi: https://doi.org/10.1590/S0080-623420150000400014.

2. Vituri DW, Évora YDM. Gestão da Qualidade Total e enfermagem hospitalar: uma revisão integrativa de literatura. Rev Bras Enferm. 2015 out;68(5):945-52. doi: https://doi.org/10.1590/0034-7167.2015680525i.

3. Agência Nacional de Vigilância Sanitária (BR). Resolução RDC n.15, de 15 de março de 2012. Dispõe sobre requisitos de boas práticas para o processamento de produtos para saúde e dá outras providências. Brasília; 2012 [citado 2019 jan 9]. Disponível em: http://bvsms.saude.gov.br/bvs/saudelegis/anvisa/2012/ rdc0015_15_03_2012.html.

4. Organização Mundial da Saúde (CH). Segundo desafio global para a segurança do paciente: cirurgias seguras salvam vidas. Brasília: OPAS, ANVISA, Ministério da Saúde; c2009 [cited 2019 Jan 9]. Available from: http://bvsms.saude.gov. br/bvs/publicacoes/seguranca_paciente_cirurgias_seguras_salvam_vidas. pdf.

5. Tanaka K, Eriksson L, Asher R, Obermair, A. Incidence of adverse events, preventability and mortality in gynaecological hospital admissions: a systematic review and meta-analysis. Aust N Z J Obstet Gynaecol. 2019 Jan;59(2):195-200. doi: https://doi.org/10.1111/aj0.12937.

6. Vincent C, Amalberti R. Cuidado de saúde mais seguro: estratégias para 0 cotidiano do cuidado. Rio de Janeiro: Fiocruz; 2016 [cited 2019 Feb 10]. Available from: https://proqualis.net/sites/proqualis.net/files/Cuidado\%20 de\%20Sa\%C3\%BAde\%20mais\%20Seguro\%20-\%20PDF.pdf.

7. Anderson 0, Rachel D, Hanna GB, Vincent CA. Surgical adverse events: a systematic review. Am J Surg. 2013 Aug;206(2):253-62. doi: https://doi. org/10.1016/j.amjsurg.2012.11.009
8. Loh HP, de Korne DF, Chee SP, Mathur R. Reducing wrong intraocular lens implants in cataract surgery: 3 years of experience with the SEIPS framework in Singapore. Int J Health Care Qual Assur. 2017 Dec;30(6):492-505. doi: https:// doi.org/10.1108/IJHCQA-06-2016-0095.

9. Castilho VGV. Gerenciamento em enfermagem. Rio de Janeiro: Guanabara Koogan; 2016.

10. Van Meter MM, Adam RA. Costs associated with instrument sterilization in gynecologic surgery. Am J Obstet Gynecol. 2016 Nov;215(5):652e1-5. doi: https://doi.org/10.1016/j.ajog.2016.06.019.

11. Fetters MD, Curry LA, Creswell JW. Achieving integration in mixed methods designs-principles and practices. Health Serv Res. 2013 Dec;48(6):2134-56. doi: https://doi.org/10.1111/1475-6773.12117.

12. Rodrigues MV. Ações para a qualidade: gestão estratégica e integrada para a melhoria dos processos na busca da qualidade e competitividade. 5. ed. Rio de Janeiro: Elsevier; 2014.

13. Boe WJ, Cheng CH. Close neighbour algorithm for designing cellular manufacturing systems. Int J Prod Res. 1991;29:2097-116. doi: https://doi. org/10.1080/00207549108948069.

14. Hair JF, Black WC, Babin BJ, Anderson RE, Tathan RL. Análise multivariada de dados. 6. ed. Porto Alegre: Bookman; 2009.

15. Oliveira JLC, Magalhães AMM, Matsuda LM. Métodos mistos na pesquisa em enfermagem: possibilidades de aplicação à luz de Creswell. Texto Contexto Enferm. 2018 jun;27(2):e0560017. doi: https://doi.org/10.1590/0104070720180000560017.

16. Bardin, L. Analise de conteúdo. Lisboa: Edições 70; 2009.

17. Mhlaba JM, Stockert EW, Coronel M, Langerman AJ. Surgical instrumentation: the true cost of instrument trays and a potential strategy for optimization. J Hosp Admin. 2015 Sept;(6):82-8. doi: https://doi.org/10.5430/jha.v4n6p82.

18. Koyle MA, AlQarni N,Odeh R, ButtH, Alkahtani MM, KonstantL, etal. Reduction and standardization of surgical instruments in pediatric inguinal hernia repair. J Pediatr Urol. 2018 Feb;14(1):20-4. doi: https://doi.org/10.1016/j.jpurol.2017.08.002.

19. Farrokhi FR, Gunther M, Williams B, Blackmore CC. Application of lean methodology for improved quality and efficiency in operating room instrument availability. J Healthc Qual. 2015 Sept;37(5):277-86. doi: https://doi. org/10.1111/jhq.12053.

20. Byrnes JN, Schmitt J, Tommaso C, Occhino JA. Cost reduction techniques in the operating suite: surgical tray optimization [non-oral poster]. Am J Obstetr Gynecol. 2017 Mar;216(3 Suppl):S616. doi: https://doi.org/10.1016/j. ajog.2016.12.119.

\title{
- Corresponding author:
}

Daniela Santos Schneider

E-mail: danielassantos@hcpa.edu.br

\author{
Associate editors: \\ Ana Karina Silva da Rocha Tanaka \\ Cecília Helena Glanzner
}

Received: 04.06.2019

Editor-in-chief:

Approved: 05.30.2019

Maria da Graça Oliveira Crossetti 